\title{
Terénní testování prototypu separátoru k dočištění srážkových vod
}

\section{JANA ČEJKOVÁ, ANNA KÓLOVÁ, JIŘí KUČERA, MIROSLAV VÁŇA, MAREK HOLBA, PAVEL POLÁŠEK}

\author{
Klíčová slova: srážkový odtok - srážkové smyvy - čištění - separace polutantů - \\ nerozpuštěné látky - polycyklické aromatické uhlovodíky - těžké kovy
}

\section{SOUHRN}

\begin{abstract}
Článek shrnuje poznatky získané v rámci řešení výzkumného projektu „Technologie separace specifických polutantů ze srážkových vod" (TH03030223), který se zabýval čištěním srážkových vod ze zpevněných ploch a komunikací zatížených nerozpuštěnými látkami (NL), polycyklickými aromatickými uhlovodíky i těžkými kovy. Projekt si kladl za cíl vyvinout účinnou technologii, která by uvedené polutanty ze srážkových vod separovala. Testování separačního zařizení v modelovém a následně poloprovozním měřítku na dvou lokalitách prokázalo svoji účinnost při záchytu NL. Provedenými zkouškami zařizení byl potvrzen předpoklad, že odstraněním NL se zásadně sniží také odtokové koncentrace polyaromatických uhlovodíků a těžkých kovů. Použití separátoru k dočištění srážkových vod tak přispívá ke snižení zátěže povrchových nebo podzemních vod dalšími polutanty, zejména polycyklickými aromatickými uhlovodíky a těžkými kovy.
\end{abstract}

\section{ÚVOD}

Jeden z významných potenciálních zdrojů kontaminace povrchových a podzemních vod v urbanizovaném území představují vody odtékající při srážkách z komunikací a zpevněných ploch (dálnice, silnice, parkoviště, obratiště automobilů). Splachovaný silniční sediment obsahuje různé částice a materiály, včetně anorganického i organického znečištění, jako jsou nerozpuštěné látky (NL), těžké kovy ( $\mathrm{As}, \mathrm{Cd}, \mathrm{Cr}, \mathrm{Cu}, \mathrm{Ni}, \mathrm{Pb}$ a $\mathrm{Zn}$ ) a polycyklické aromatické uhlovodíky (PAU). Těžké kovy a PAU ve srážkovém splachu pocházejí ze spalování pohonných hmot, opotřebení částí automobilů (brzdy, pneumatiky, koroze), vozovky a dalších zdrojů. Tyto látky se hromadí na povrchu vozovky v důsledku jejího pravidelného používání a následně jsou odplavovány při srážkách do kanalizace a případně recipientu [1-3]. Splachované znečištění je jak z hlediska množství, tak i konkrétního složení v jednotlivých prípadech velmi různorodé a závisí na více faktorech. Mezi nejvýznamnější patří účel využití plochy a míra jejího zatížení. Při samotném splachu závisí také na proměnlivých přírodních podmínkách (počasí), zejména na intenzitě srážek, jež souvisí s následným odtokem vody a odnosem znečištění. Důležitým faktorem je i počet bezdeštných dnů před splachem, tedy doba, po kterou se znečištění na ploše kumuluje [3, 4]. Tyto předpoklady potvrzují Lee a kol. [3], kteři ve své studii uvedli, že největší míru znečištění na zkoumané ploše zaznamenali při nejintenzivnější srážce a současně nejdelším počtu bezdeštných dní (6 dní). Li et al. [5] ve své práci uvádějí, že koncentrace částic $v$ odtoku klesá s dobou trvání srážky. Podobné závěry byly dosaženy i v našich dřive provedených simulovaných srážkových splaších, kde byla sledována koncentrace NL, PAU a těžkých kovů v první a páté minutě simulovaného splachu ze zpevněných ploch. Výsledky prokázaly, že již mezi těmito časy významně klesá množství NL a zároveň se snižuje koncentrace PAU a těžkých kovů [6]. V literatuře bylo publikováno mnoho vhodných postupů ke snížení PAU a těžkých kovů ze srážkových vod, např. sedimentace, filtrace [1] nebo koagulace kombinovaná s flokulací [4]. Separace NL se jeví jako významný proces ke snižení znečistění [1]. Výběr vhodné technologie pro konkrétní aplikaci vychází z míry zatížení a s tím souvisejícím znečištěním zvolené plochy, dále z požadované kvality vyčištěné vody, eventuálně možnosti jejího dalšího využití a investičních nákladů [7].

Výzkumný projekt s názvem „Technologie separace specifických polutantů ze srážkových vod" (TH03030223) se zaměřil na odstraňování znečištění ze srážkových vod odtékajících ze zpevněných ploch. Cílem projektu bylo vyvinout prototyp separačního zařizení, jež by bylo specializováno na odstraňování především NL a na ně navázaného znečištění, zejména PAU a těžkých kovů, a ve kterém by probíhalo předčištění srážkových vod před jejich vsakováním do podzemních vod, vypouštěním do vod povrchových, případně před jejich dalším možným využitím [6]. Navržené a v poloprovozních podmínkách ověřené zařízení je založeno na separaci co největšího podílu NL. Kjeho návrhu bylo využito matematického modelování proudění vody. $V$ rámci řešení se předpokládalo, že vyvíjený separátor bude osazen jako podzemní objekt, který se nebude čistit po každé srážce. Separační prostor bude trvale zatopen vodou. Po začátku srážky se tedy zařízení nebude plnit, ale voda začne rovnou odtékat. Zařízení neslouží k transformaci (zploštění) průtoků při deštové srážce. Zachycené NL se usazují u dna a prepážka, umístěná těsně nade dnem, brání jejich opětovnému vyplavování při další srážce. Množství zachycených látek se bude postupně zvyšovat. Po zaplnění kalové části zařízení bude potřeba provést vyčištění separátoru, aby nedošlo k vyplavování zachyceného znečištění, a tím ke snižování účinnosti zařízení. Naplnění kalové části je individuální a závislé na podmínkách dané lokality (typ odvodňované plochy, prašnost, provoz a další), proto je nezbytné provádět průběžné měěení množství kalu. $V$ rámci projektu nebyla doba naplnění sledována, jelikož se jedná o dlouhodobé měření. Prototyp zařízení byl testován v poloprovozních podmínkách nad úrovní terénu.

\section{METODIKA}

$\checkmark$ rámci řešení projektu byly nejprve provedeny analýzy simulovaných deštových splachů ze zpevněných ploch. Navazující fáze projektu byla zaměřena na zpracování a analýzu výsledků splachů a provedení matematického modelování, na jejichž základě bylo přistoupeno k vývoji modelu separačního zařízení k odstranění NL a jeho odzkoušení v laboratorních podmínkách v závislosti na velikosti frakce a průtoku. Návrh a optimalizace prototypu zařízení vycházely 
z hydrodynamického modelování a výsledků laboratorního zkoušení. Zařízeni bylo konstruováno tak, aby byl co nejvhodněji využit celkový objem separátoru a nedocházelo ke zkratovému proudění. Jedním z hlavních aspektů při návrhu konstrukce, za účelem nejúčinnější sedimentace, byla délka trajektorie a její čas. Dále byl kladen důraz na způsob provozování a ekonomiku provozu a také na investiční a výrobní náklady vyvinutého zařízení. Výsledky laboratorních fází projektu již byly publikovány dřive [8]. Tento príispěvek se zabývá závěrečnou fází projektu, tedy terénním testováním prototypu separátoru s návrhovým průtokem 1 | $\cdot$ - $^{-1}$ (viz obr. 1 a 2), v poloprovozních podmínkách.

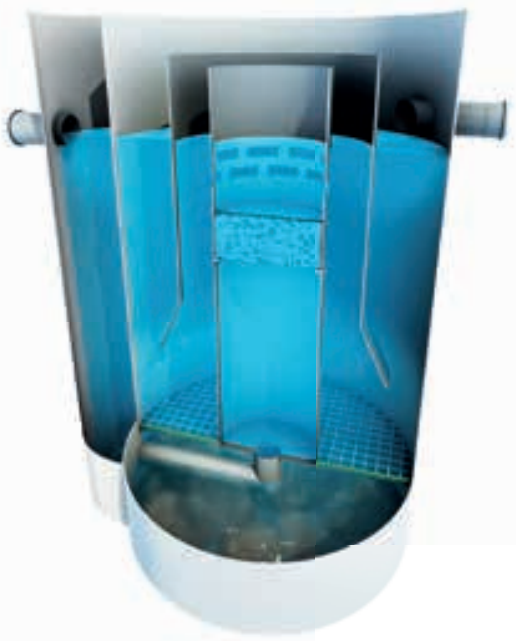

Obr. 1. Vizualizace prototypu separačního zařizení

Fig. 1. Visualization of a prototype separation device

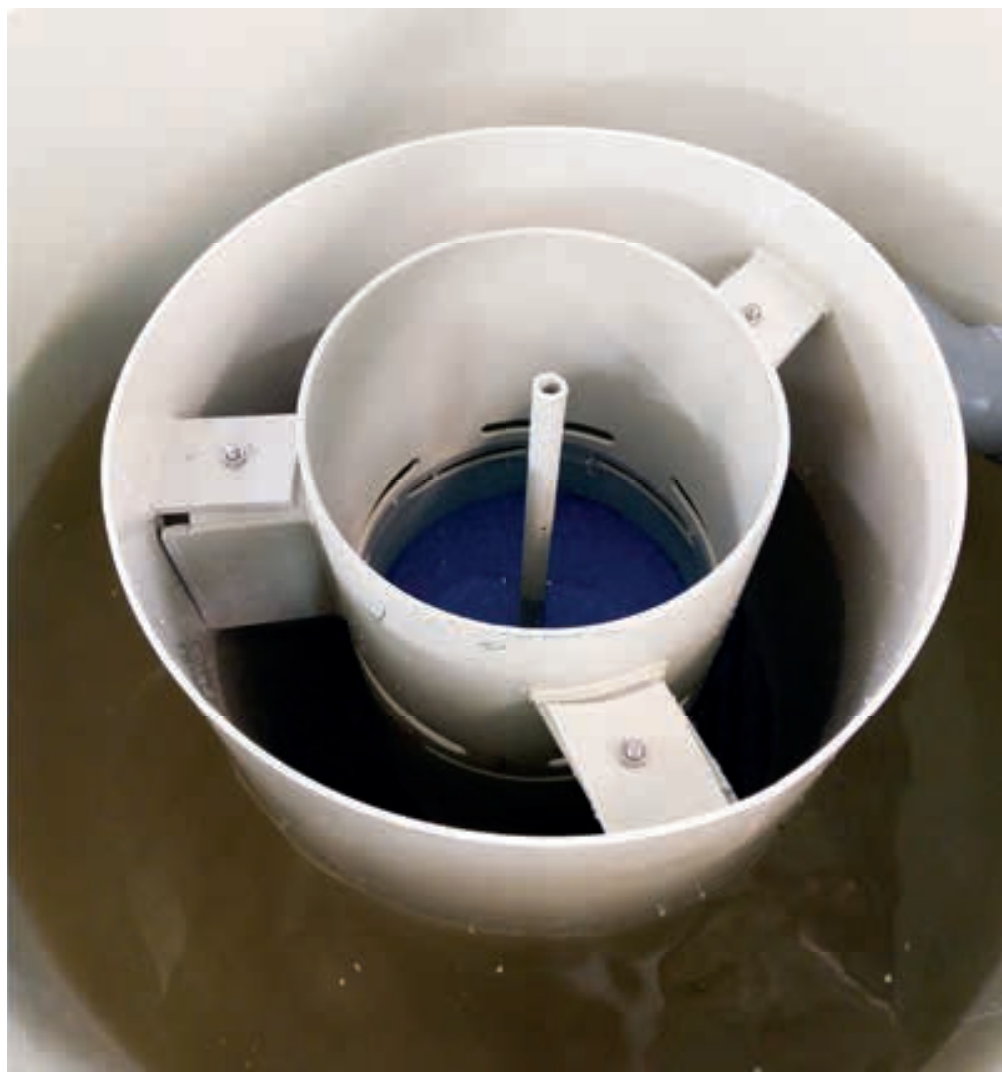

Obr. 2. Detail prototypu separačního zařízení

Fig. 2. Detail of a prototype separation device
Simulované splachy (při třech zvolených průtocích) byly provedeny na dvou lokalitách. Hodnoty průtoků vycházely z matematického modelování proudění v zařízení. Z provozních důvodů bylo na začátku řešení projektu zvoleno, že měření i další testování se bude provádět při simulovaném dešti, tedy omytím zpevněné plochy pitnou vodou z hydrantu po dlouhodobějším období beze srážek. Simulace srážky probíhala tak, aby celá plocha byla skrápěna co možná nejrovnoměrněji a mohlo být regulováno množství průtoku zařízením. Mezi jednotlivými testy nebyl prototyp čištěn, pouze vypuštěn, aby mohl být přemístěn a uskladněn. Pro testování se předpokládal termín po období jednoho až dvou týdnů bez deštů i krátkodobých přeháněk (konkrétně specifikováno v kapitole Výsledky a diskuze).

Na obou měřených lokalitách bylo zařízení zkoušeno postupně při těchto průtocích (Q):

- Snížený průtok 0,5 I. - $^{-1}$

- Nominální průtok 1 1. $\mathrm{s}^{-1}$

- Maximální průtok 1,5 I. $\mathrm{s}^{-1}$

Intenzita oplachu povrchu vozovky pitnou vodou z hydrantu (simulace srážky) byla regulována tak, aby odpovídala zkoušenému průtoku. Přítok do prototypu byl regulován a kontrolován průtokoměrem. Těsně před započetím testu byl odebrán prostý vzorek vstupní vody z hydrantu, ve kterém byly stanoveny $\mathrm{NL}$ prì $105^{\circ} \mathrm{C}$ (slepý pokus).

Zařízení bylo instalováno na volných plochách zvolených lokalit jako nadzemní nádrž. Hlavním dưvodem byla nutnost přesouvání prototypu mezi lokalitami a především nebylo možné v daných lokalitách zařízení zabudovat pod úroveň terénu ani uskladnit na ploše do další série testování. Lokality byly zvoleny s ohledem na odlišný způsob používání.

Splachy byly provedeny na dvou zvolených lokalitách:

— Lokalita 1: plocha, kde se otáčejí nákladní automobily

- Lokalita 2: plocha, na níž pravidelně parkují nákladní vozidla

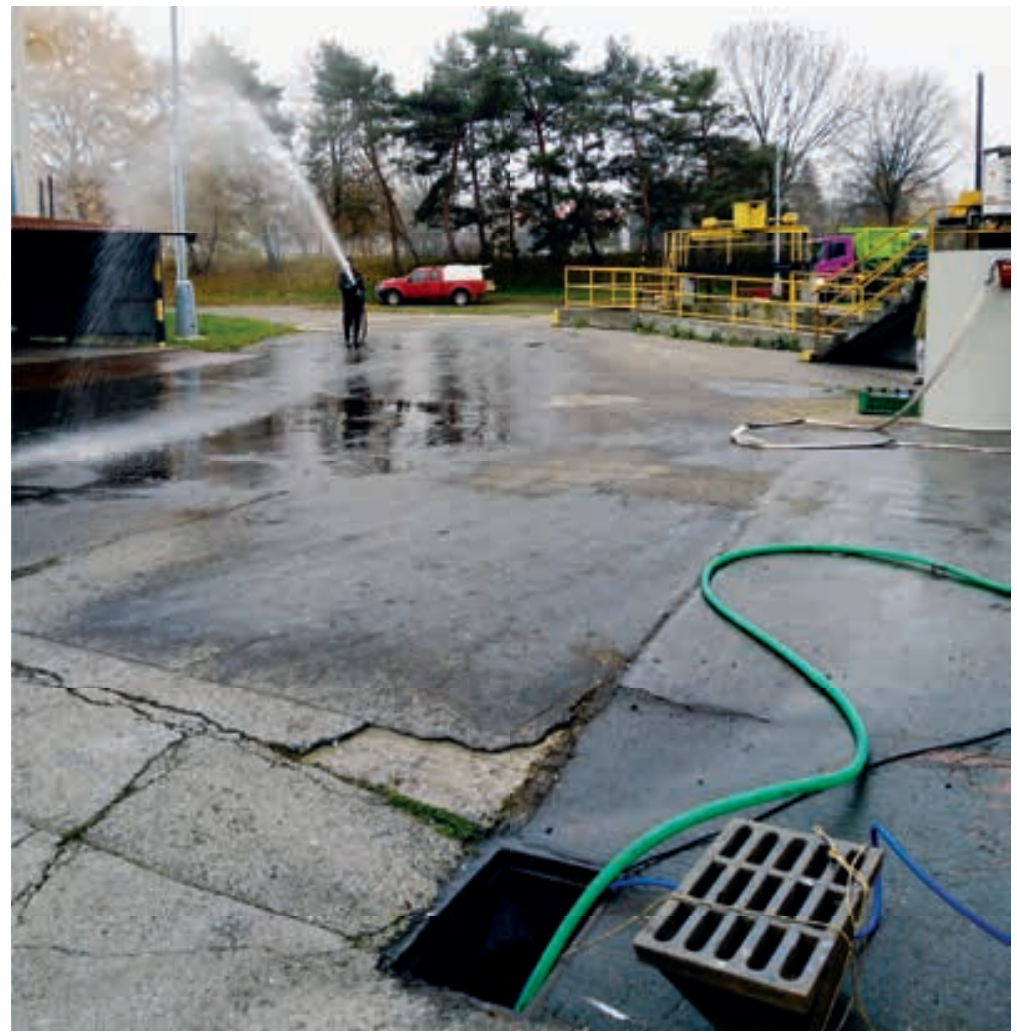

Obr. 3. Pohled na splach - lokalita

Fig. 3. View of the run-off - locality 


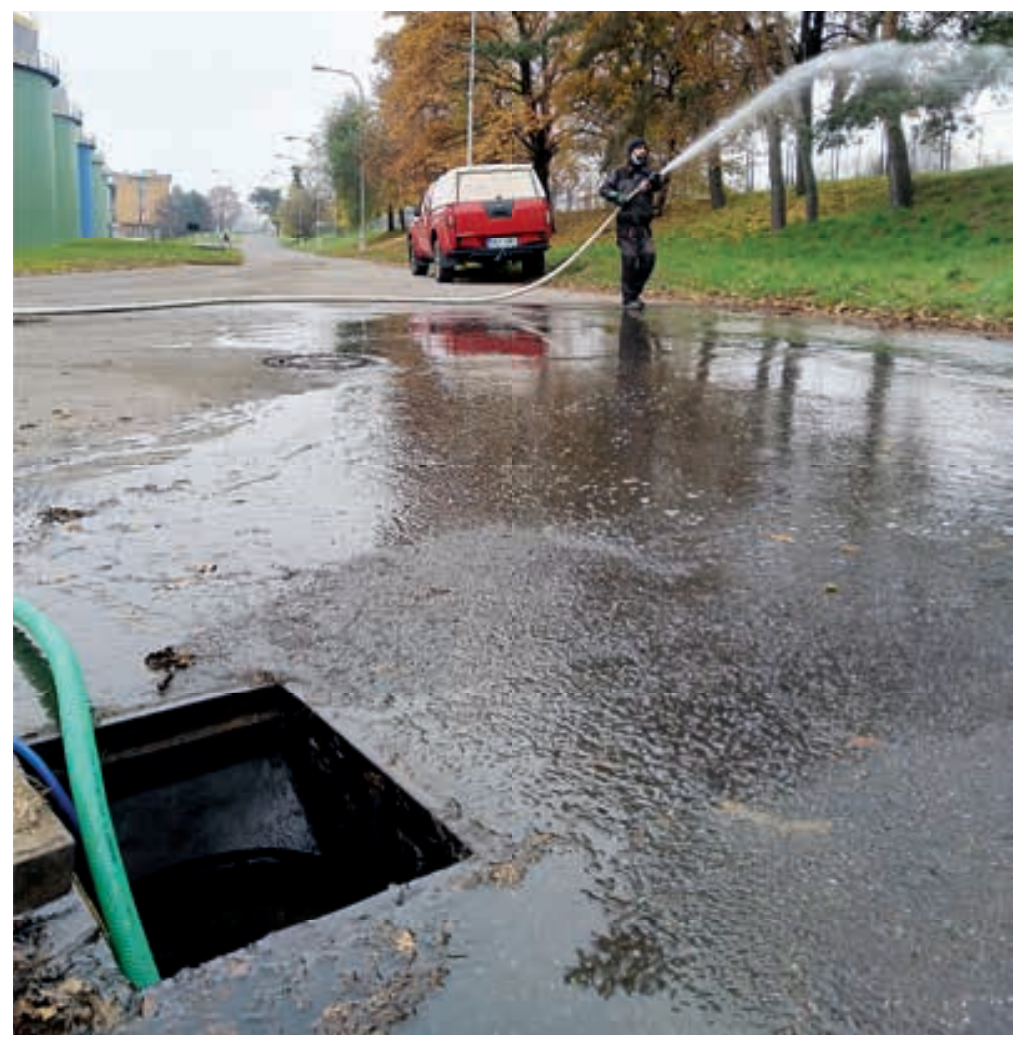

Obr. 4. Pohled na splach - lokalita 2

Fig. 4. View of the run-off - locality 2

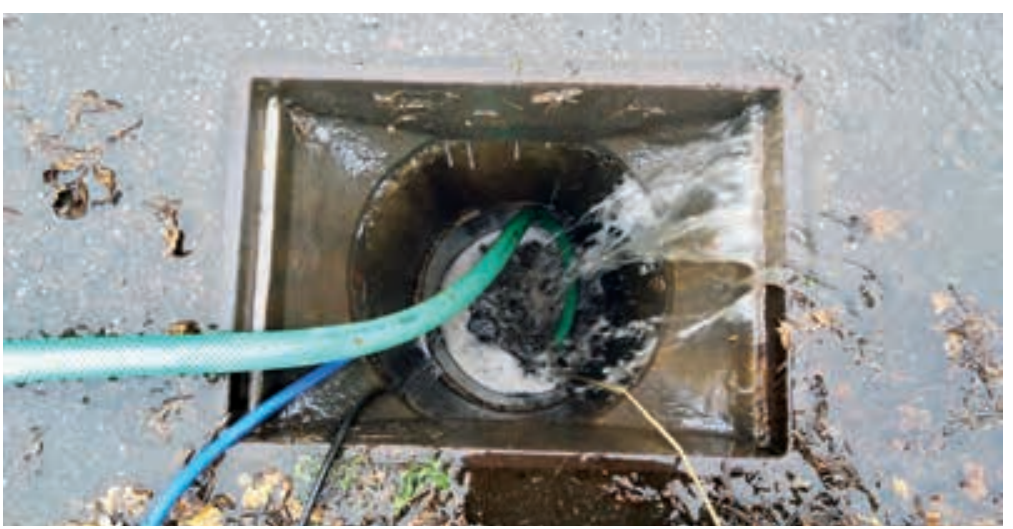

Obr. 5. Pohled na utěsněnou vpust' (lokalita 2)

Fig. 5. View of a sealed drain (locality 2)

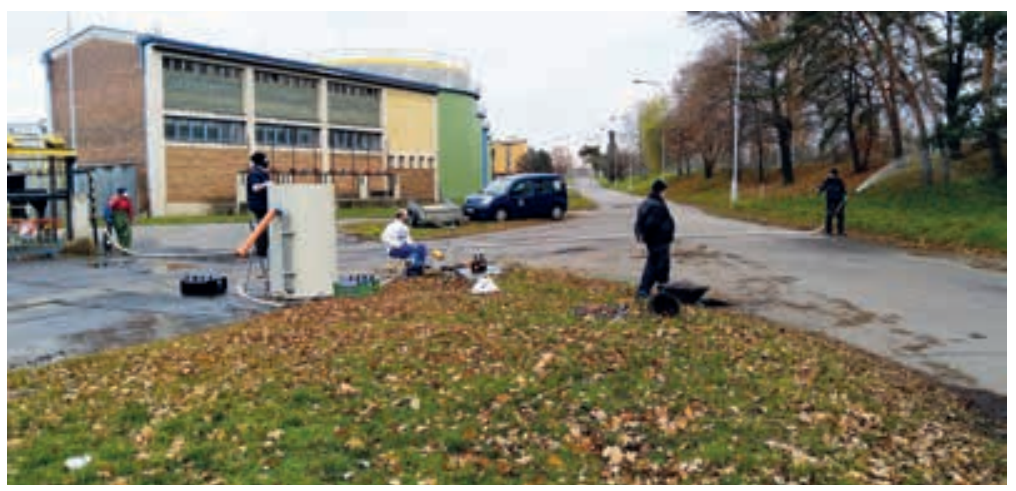

Obr. 6. Pohled na testování - lokalita 2

Fig. 6. View of the testing - locality 2

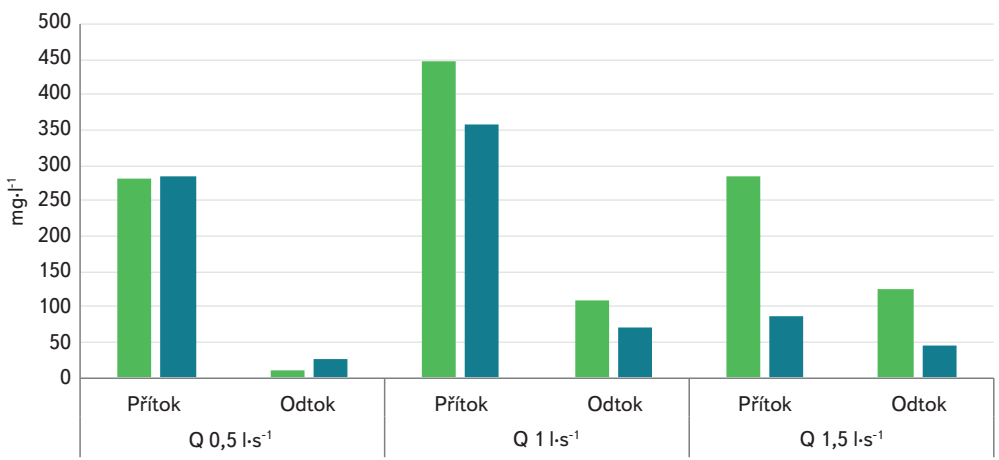

\section{Lokalita 1 Lokalita 2}

Obr. 7. Průměrné koncentrace NL na prítoku a odtoku - porovnání obou lokalit Fig. 7. Inflow and outflow suspended solids average concentrations - comparison between localities 1 and 2

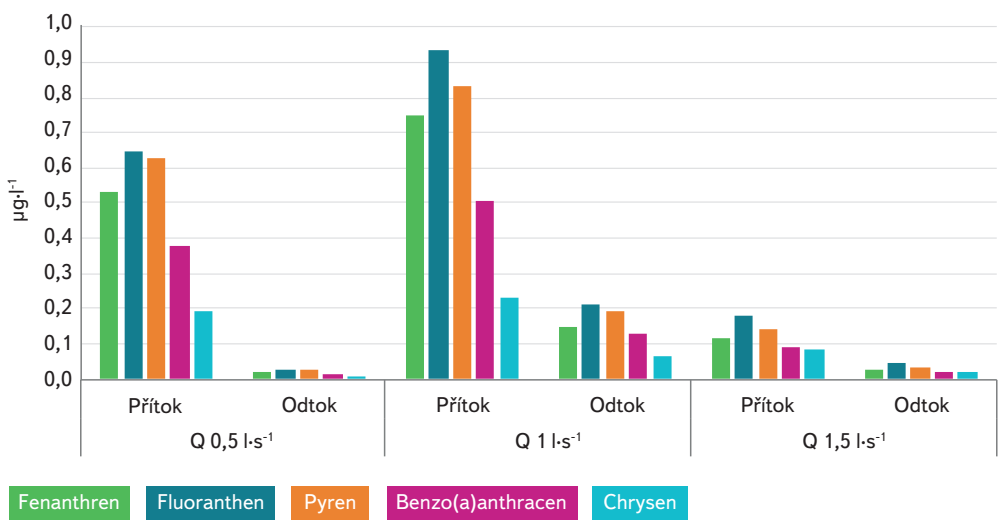

Obr. 8. Průměrné koncentrace významných PAU na př́toku a odtoku - lokalita 1 Fig. 8. Average concentrations of significant PAH in influent and effluent - locality 1

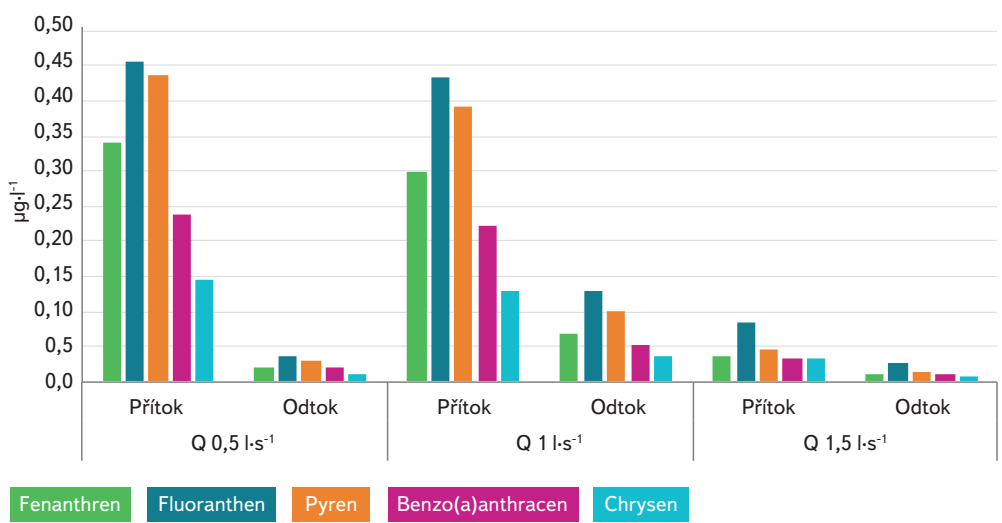

Obr. 9. Průměrné koncentrace významných PAU na prítoku a odtoku - lokalita 2 Fig. 9. Average concentrations of significant PAH in influent and effluent - locality 2

Zkoumaná plocha byla postřikována vodou z hydrantu tak, aby bylo rovnoměrně skrápěno celé vytyčené území, z něhož voda stékala k vybrané kanalizační vpusti (obr. 3 a 4). Na vpusti byl vyjmut poklop, ucpávkou utěsněn odtok do kanalizace (obr. 5) a stékající voda byla inned ze vpusti kalovým čerpadlem přiváděna do prítokové části prototypu. Př́toková hadice byla osazena průtokoměrem s regulovatelným uzávěrem. Pohled na testování je znázorněn na obr. 6. Na základě zpracování hydrodynamického matematického modelování a zkušeností z pilotní fáze testování prototypu v laboratorních podmínkách byla navržena celková délka zkoušení 15 minut. Program odběru vzorků reflektoval předpoklad, že největší množství NL je ze zpevněné plochy spláchnuto 
Tab. 1. Hodnoty NL stanovené na prítoku a odtoku na lokalitě 1

Tab. 1. Suspended solids concentration values determined in influent and effluent at locality 1

\begin{tabular}{|c|c|c|c|c|}
\hline $\begin{array}{l}\text { Čas odběru } \\
\text { min. }\end{array}$ & Místo odběru & $\begin{array}{l}\mathbf{Q} 0,5 \mathrm{l} \cdot \mathrm{s}^{-1} \\
{\left[\mathrm{mg} \cdot \mathrm{I}^{-1}\right]}\end{array}$ & $\begin{array}{l}\text { Q } 1 \mathrm{l} \cdot \mathrm{s}^{-1} \\
{\left[\mathrm{mg} \cdot \mathrm{I}^{-1}\right]}\end{array}$ & $\begin{array}{l}\text { Q 1,5 } \mathrm{l} \cdot \mathrm{s}^{-1} \\
{\left[\mathrm{mg} \cdot \mathrm{I}^{-1}\right]}\end{array}$ \\
\hline 1. & Přítok & 230 & 820 & 510 \\
\hline 3. & Přítok & 240 & 740 & 290 \\
\hline 9. & Přítok & 270 & 150 & 240 \\
\hline 15. & Přítok & 390 & 84 & 100 \\
\hline Průmèr & Přítok & 283 & 449 & 285 \\
\hline 1. & Odtok & 8,8 & 54 & 60 \\
\hline 3. & Odtok & 5,2 & 31 & 94 \\
\hline 9. & Odtok & 6,0 & 160 & 170 \\
\hline 15. & Odtok & 25 & 190 & 170 \\
\hline Průměr & Odtok & 11 & 109 & 124 \\
\hline
\end{tabular}

v první fázi deště a poté se množství NL již snižuje. Vzorky na stanovení PAU, těžkých kovů a NL byly odebírány na prítoku a odtoku do prototypu současně jako prosté vzorky prímo do vzorkovnice v 1., 3., 9. a 15. minutě. Stanovení NL vycházelo z postupu vypracovaného na základě normy ČNS EN 872.

\section{VÝSLEDKY A DISKUZE}

Je známo, že se zvyšující se intenzitou srážky roste i intenzita splachu a mohou se potenciálně odplavit i větší části znečištění, takže teoreticky by mělo platit, že čím větší je intenzita srážky, tím větší znečištění na př́toku může být. Nicméně vzhledem k uplatněné metodice experimentů, kdy byly používány simulované srážky na lokalitách, nebylo možné dosáhnout vždy stejných počátečních podmínek (stejný počet bezdeštných dnů, stejné zatížení plochy sledovanými látkami). Pro řešení projektu byl za bezdeštný den považován takový den, jehož denní úhrn srážek nepřesahoval 0,25 mm (aby nedocházelo k odtoku znečištění do kanalizace). Rozdíly v počátečních koncentracích NL jsou patrné z výsledků na obr. 7 , kdy jejich nejvyšší koncentrace byla detekována při průtoku 1 l·s'-1.
Tab. 2. Hodnoty NL stanovené na prítoku a odtoku na lokalitě 2

Tab. 2. Suspended solids concentration values determined in influent and effluent at locality 2

\begin{tabular}{|c|c|c|c|c|}
\hline $\begin{array}{l}\text { Čas odběru } \\
\text { min. }\end{array}$ & Místo odběru & $\begin{array}{l}\mathbf{Q} 0,5 \mathrm{l} \cdot \mathrm{s}^{-1} \\
{\left[\mathrm{mg} \cdot \mathrm{I}^{-1}\right]}\end{array}$ & $\begin{array}{l}\text { Q 1 I. } \mathrm{s}^{-1} \\
{\left[\mathrm{mg} \cdot \mathrm{I}^{-1}\right]}\end{array}$ & $\begin{array}{l}\text { Q 1,5 } \mathrm{l} \cdot \mathrm{s}^{-1} \\
{\left[\mathrm{mg} \cdot \mathrm{l}^{-1}\right]}\end{array}$ \\
\hline 1. & Prítok & 290 & 530 & 100 \\
\hline 3. & Prítok & 330 & 580 & 150 \\
\hline 9. & Prítok & 260 & 240 & 50 \\
\hline 15. & Prítok & 260 & 82 & 42 \\
\hline Průměr & Přítok & 285 & 358 & 86 \\
\hline 1. & Odtok & 23 & 16 & 41 \\
\hline 3. & Odtok & 15 & 15 & 32 \\
\hline 9. & Odtok & 16 & 86 & 53 \\
\hline 15. & Odtok & 44 & 170 & 50 \\
\hline Průměr & Odtok & 25 & 72 & 44 \\
\hline
\end{tabular}

V rámci terénního testování bylo nejvíce bezdeštných dní zaznamenáno před prvním splachem $\left(Q 0,5 \mathrm{l} \cdot \mathrm{s}^{-1}\right)$, tento splach se prováděl 8. den beze srážek, druhý splach $\left(\mathrm{Q} 1 \mid \cdot \mathrm{s}^{-1}\right)$ 7. den a třetí splach $\left(\mathrm{Q} 1,5 \mid \cdot \mathrm{s}^{-1}\right)$ se uskutečnil 4. bezdeštný den. Také mezi prvním a druhým splachem byla větší prodleva (70 dní) než mezi druhým a třetím splachem (19 dní). Z tohoto důvodu je obtížné, ne-li nemožné, porovnávat vstupní koncentrace znečištění mezi sebou.

Pohled na rozložení zaznamenaného znečištění (zde reprezentováno NL) v průběhu vlastního splachu prezentují tab. 1 a 2. Oproti očekávání, že s postupem času se budou koncentrace NL v přitoku snižovat, je $v$ těchto výsledcích patrná určitá anomálie u lokality 1, kdy se množství NL ke konci splachu při nejnižším průtoku zvyšovalo. To je pravděpodobně ovlivněno nerovnoměrným zatížením plochy znečištujuícími látkami, kdy se část znečištění mohla spláchnout později. $V$ dalších dvou měřeních a na obou lokalitách již podle předpokladu koncentrace NL s príibývajícím časem klesá. Hodnoty koncentrací v odtoku ze separačního zařízení mají opačnou tendenci, tedy se s postupem času zvyšují, což je dáno dobou zdržení znečištění v separátoru. Z výsledků je také patrné, že průtok, který bude v reálu odpovídat intenzitě srážky, má vliv na separační účinnost zařízení. Při vyšším průtoku se zhoršují podmínky pro sedimentaci NL, jež se vyplavují ve vyšší miře v porovnání s výsledky dosaženými

Tab. 3. Srovnání koncentrací těžkých kovů na prítoku a odtoku na lokalitě 1 - průmërné koncentrace za celý test

Tab. 3. Comparison of heavy metals concentrations in influent and effluent at locality 1 - average concentrations measured during the test

\begin{tabular}{|c|c|c|c|c|c|c|c|c|}
\hline $\mathbf{Q}\left[\mathbf{l} \cdot \mathrm{s}^{-1}\right]$ & $\begin{array}{l}\text { Místo } \\
\text { odběru }\end{array}$ & $\begin{array}{l}\text { Arsen } \\
{\left[\mu \mathrm{g} \cdot \mathrm{I}^{-1}\right]}\end{array}$ & $\begin{array}{l}\text { Kadmium } \\
{\left[\mu \mathrm{g} \cdot \mathrm{I}^{-1}\right]}\end{array}$ & $\begin{array}{l}\text { Olovo } \\
{\left[\left.\mu \mathrm{g} \cdot\right|^{-1}\right]}\end{array}$ & $\begin{array}{l}\text { Chrom } \\
{\left[\mu \mathrm{g} \cdot \mathrm{I}^{-1}\right]}\end{array}$ & $\begin{array}{l}\text { Měd' } \\
{\left[\mu \mathrm{g} \cdot \mathrm{I}^{-1}\right]}\end{array}$ & $\begin{array}{l}\text { Nikl } \\
{\left[\left.\mu \mathbf{g} \cdot\right|^{-1}\right]}\end{array}$ & $\begin{array}{l}\text { Zinek } \\
{\left[\mu \mathrm{g} \cdot \mathrm{I}^{-1}\right]}\end{array}$ \\
\hline 0,5 & Prítok & 2,26 & 0,34 & 24,5 & 4,0 & 29,5 & 9,0 & 693 \\
\hline 0,5 & Odtok & 0,5 & 0,05 & 0,93 & 1,5 & 4,0 & 4,0 & 31,3 \\
\hline 1 & Prítok & 2,74 & 0,36 & 38,1 & 5,8 & 38,0 & 9,5 & 1091 \\
\hline 1 & Odtok & 0,9 & 0,11 & 6,59 & 1,9 & 8,5 & 4,0 & 199 \\
\hline 1,5 & Přítok & 2,04 & 0,22 & 19,0 & 2,5 & 13,5 & 8,8 & 884 \\
\hline 1,5 & Odtok & 0,90 & 0,05 & 1,96 & 1,5 & 4,0 & 4,0 & 43,5 \\
\hline
\end{tabular}


Tab. 4. Srovnání koncentrací těžkých kovů na prítoku a odtoku na lokalitě 2 - prüměrné koncentrace za celý test

Tab. 4. Comparison of heavy metals concentrations in influent and effluent at locality 2 - average concentrations measured during the test

\begin{tabular}{|c|c|c|c|c|c|c|c|c|}
\hline $\mathbf{Q}\left[\mathbf{I} \cdot \mathbf{s}^{-1}\right]$ & $\begin{array}{l}\text { Místo } \\
\text { odběru }\end{array}$ & $\begin{array}{l}\text { Arsen } \\
{\left[\mu \mathrm{g} \cdot \mathrm{I}^{-1}\right]}\end{array}$ & $\begin{array}{l}\text { Kadmium } \\
{\left[\mu \mathrm{g} \cdot \mathrm{I}^{-1}\right]}\end{array}$ & $\begin{array}{l}\text { Olovo } \\
{\left[\mu \mathrm{g} \cdot \mathrm{I}^{-1}\right]}\end{array}$ & $\begin{array}{l}\text { Chrom } \\
{\left[\mu \mathrm{g} \cdot \mathrm{I}^{-1}\right]}\end{array}$ & $\begin{array}{l}\text { Měd' } \\
{\left[\left.\mu \mathrm{g} \cdot\right|^{-1}\right]}\end{array}$ & $\begin{array}{l}\text { Nikl } \\
{\left[\mu \mathrm{g} \cdot \mathbf{l}^{-1}\right]}\end{array}$ & $\begin{array}{l}\text { Zinek } \\
{\left[\mu \mathrm{g} \cdot \mathrm{I}^{-1}\right]}\end{array}$ \\
\hline 0,5 & Prítok & 2,88 & 0,37 & 20,2 & 5,75 & 27,8 & 9,25 & 212 \\
\hline 0,5 & Odtok & 0,63 & 0,05 & 1,38 & 1,5 & 4,0 & 4,0 & 36,3 \\
\hline 1 & Prítok & 2,63 & 0,23 & 19,8 & 5,88 & 28,8 & 10,8 & 254 \\
\hline 1 & Odtok & 1,01 & 0,09 & 3,96 & 1,88 & 7,0 & 4,0 & 64,8 \\
\hline 1,5 & Prítok & 1,96 & 0,10 & 10,1 & 1,5 & 8,0 & 5,0 & 119 \\
\hline 1,5 & Odtok & 0,90 & 0,05 & 1,96 & 1,5 & 4,0 & 4,0 & 43,5 \\
\hline
\end{tabular}

Tab. 5. Srovnání koncentrací PAU na prítoku a odtoku na lokalitě 1 - prüměrné koncentrace za celý test

Tab. 5. Comparison of PAH concentrations in influent and effluent at locality 1 - average concentrations measured during the test

\begin{tabular}{|c|c|c|c|c|c|c|c|}
\hline $\mathbf{Q}\left[\mid \cdot \mathbf{S}^{-1}\right]$ & $\begin{array}{l}\text { Místo } \\
\text { odběru }\end{array}$ & $\begin{array}{l}\text { Suma všech } \\
\text { PAU }\left[\left.\mu g \cdot\right|^{-1}\right]\end{array}$ & $\begin{array}{l}\text { Fenanthren } \\
{\left[\left.\mu \mathrm{g} \cdot\right|^{-1}\right]}\end{array}$ & $\begin{array}{l}\text { Fluoranthen } \\
{\left[\mu \mathrm{g} \cdot \mathrm{I}^{-1}\right]}\end{array}$ & $\begin{array}{l}\text { Pyren } \\
{\left[\left.\mu g \cdot\right|^{-1}\right]}\end{array}$ & $\begin{array}{l}\text { Benzo(a)anthracen } \\
{\left[\mu \mathrm{g} \cdot \mathrm{I}^{-1}\right]}\end{array}$ & $\begin{array}{l}\text { Chrysen } \\
{\left[\left.\mu g \cdot\right|^{-1}\right]}\end{array}$ \\
\hline 0,5 & Přítok & 3,30 & 0,53 & 0,65 & 0,63 & 0,38 & 0,19 \\
\hline 0,5 & Odtok & 0,14 & 0,02 & 0,03 & 0,02 & 0,01 & 0,01 \\
\hline 1 & Přítok & 4,35 & 0,75 & 0,93 & 0,83 & 0,51 & 0,23 \\
\hline 1 & Odtok & 1,12 & 0,15 & 0,21 & 0,19 & 0,13 & 0,07 \\
\hline 1,5 & Přítok & 1,07 & 0,11 & 0,18 & 0,14 & 0,09 & 0,08 \\
\hline 1,5 & Odtok & 0,25 & 0,03 & 0,05 & 0,03 & 0,02 & 0,02 \\
\hline
\end{tabular}

Tab. 6. Srovnání koncentrací PAU na prítoku a odtoku na lokalitě 2 - prüměrné koncentrace za celý test

Tab. 6. Comparison of PAH concentrations in influent and effluent at locality 2 - average concentrations measured during the test

\begin{tabular}{|c|c|c|c|c|c|c|c|}
\hline $\mathbf{Q}\left[\mid \cdot \mathbf{s}^{-1}\right]$ & $\begin{array}{l}\text { Místo } \\
\text { odběru }\end{array}$ & $\begin{array}{l}\text { Suma všech } \\
\text { PAU }\left[\left.\mu g \cdot\right|^{-1}\right]\end{array}$ & $\begin{array}{l}\text { Fenanthren } \\
{\left[\left.\mu \mathrm{g} \cdot\right|^{-1}\right]}\end{array}$ & $\begin{array}{l}\text { Fluoranthen } \\
{\left[\mu \mathrm{g} \cdot \mathrm{I}^{-1}\right]}\end{array}$ & Pyren $\left[\left.\mu g \cdot\right|^{-1}\right]$ & $\begin{array}{l}\text { Benzo(a)anthracen } \\
{\left[\left.\mu \mathrm{g} \cdot\right|^{-1}\right]}\end{array}$ & $\begin{array}{l}\text { Chrysen } \\
{\left[\left.\mu g \cdot\right|^{-1}\right]}\end{array}$ \\
\hline 0,5 & Přítok & 2,33 & 0,34 & 0,45 & 0,44 & 0,24 & 0,14 \\
\hline 0,5 & Odtok & 0,18 & 0,02 & 0,04 & 0,03 & 0,02 & 0,01 \\
\hline 1 & Přítok & 2,13 & 0,30 & 0,43 & 0,39 & 0,22 & 0,13 \\
\hline 1 & Odtok & 0,57 & 0,07 & 0,13 & 0,10 & 0,05 & 0,04 \\
\hline 1,5 & Přítok & 0,39 & 0,04 & 0,08 & 0,04 & 0,03 & 0,03 \\
\hline 1,5 & Odtok & 0,11 & 0,01 & 0,03 & 0,01 & 0,01 & 0,01 \\
\hline
\end{tabular}

Tab. 7. Pearsonův korelační koeficient; výstup pro NL a těžké kovy

Tab. 7. Pearson correlation coefficient; output for suspended solids and heavy metals

\begin{tabular}{|c|c|c|c|c|c|c|c|c|}
\hline & Suma všech kovů & Arsen & Kadmium & Olovo & Chrom & Měd' & Nikl & Zinek \\
\hline NL & 0,82 & 0,85 & 0,81 & 0,94 & 0,78 & 0,91 & 0,90 & 0,79 \\
\hline
\end{tabular}




\begin{tabular}{lllllll} 
& Suma všech PAU & Fenanthren & Fluoranthen & Pyren & Benzo(a)anthracen & Chrysen \\
\hline NL & 0,83 & 0,80 & 0,83 & 0,82 & 0,80
\end{tabular}

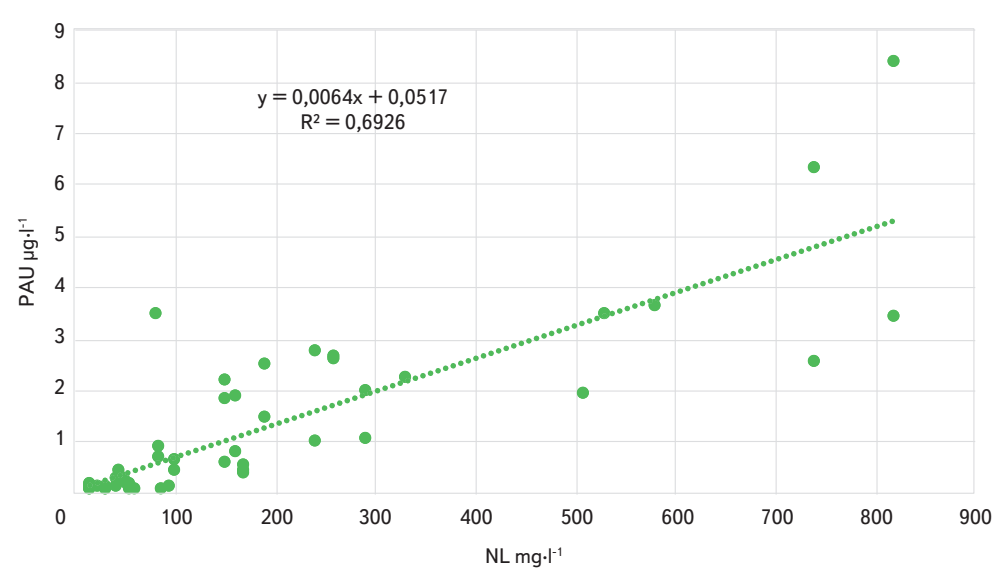

Obr. 10. Grafické znázornění vztahu mezi koncentracemi NL a PAU (suma všech PAU) Fig. 10. Graphical relation between suspended solids and PAH concentrations (the sum of all $\mathrm{PAH})$

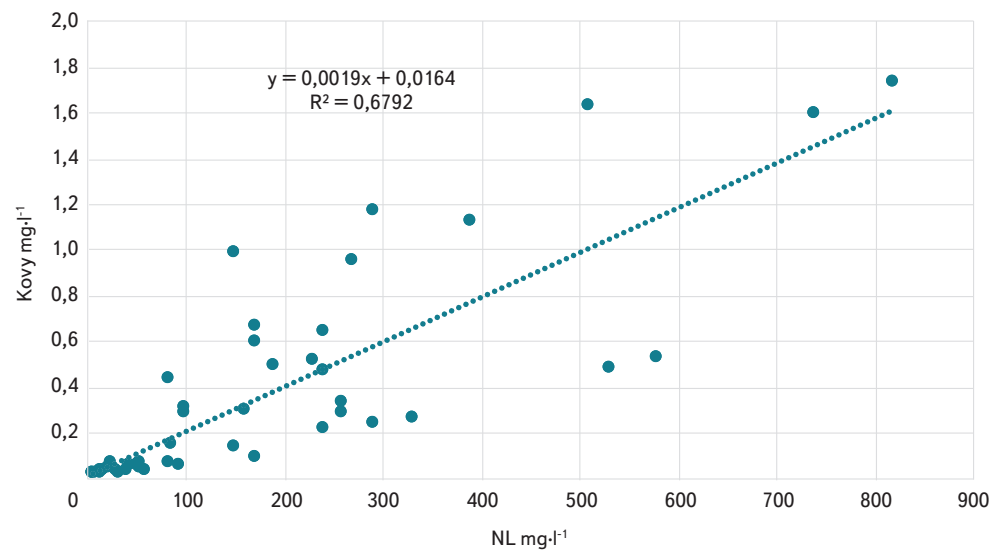

Obr. 11. Grafické znázornění vztahu mezi koncentracemi NL a těžkých kovů (suma všech těžkých kovů)

Fig. 11. Graphical relation between suspended solids and heavy metals concentrations (the sum of all heavy metals)

při nižších průtocích. Ze zařízení se vyplavují zejména hưře sedimentující malé částice (< 0,09 mm), což bylo na tomto zařízení již dřive odzkoušeno v laboratorních podmínkách [8].

Ze všech uvedených výsledků (tab. 1 až 6) je patrné, že lokalita 1 byla více zatížena sledovaným znečištěním než lokalita 2 . K rozdílưm $v$ kumulovaném znečištění dochází pravděpodobně vlivem většího zatížení lokality 1 při manipulaci nákladních aut (otáčení, krátkodobé stání s mnohdy nastartovaným motorem)

$\checkmark$ tab. 3 a 4 je přehled analyzovaných kovů z obou lokalit. Jsou zde uvedeny průměrné koncentrace za celou dobu testu z prítoku a odtoku ze separačního zařízení. Výsledky jsou uvedeny pro všechny tři testované průtoky. Z kovů na obou lokalitách nejvíce dominovaly koncentrace zinku, které mnohonásobně převyšovaly koncentrace ostatních kovů. Vyšších hodnot dále dosahovaly měd a olovo. Pro výpočet průměrů u hodnot pod mezí stanovitelnosti byla použita metoda podle vyhlášky č. 98/2011 Sb., kdy se hodnota pod mezí stanovitelnosti nahrazuje její polovinou. Suma PAU uvedená v tab. 5, 6 a 8 zahrnuje všechny analyzované PAU: naftalen, acenaften, fluoren, fenanthren, antracen, fluoranthen, pyren, benzo(a)anthracen, chrysen, benzo(b)fluoranthen, benzo(k)fluoranthen, benzo(a)pyren, benzo(g,h,i)perylen, dibenzo(a,h)anthracen a indeno $(1,2,3, c, d)$ pyren. $\vee$ tab. 5 a 6 (pro lepší názornost i obr. 8 a 9) jsou uvedeny průměrné koncentrace významných PAU. Stabilně se v analyzovaných vzorcích vyskytovaly nejvyšší koncentrace fluoranthenu a pyrenu. Nejvyšší koncentrace kovů i PAU byly analyzovány stejně jako u NL při druhém splachu (Q 1 l. $\left.s^{-1}\right)$.

Již výše uvedené výsledky naznačují, že koncentrace NL, těžkých kovů a PAU spolu souvisejí. Tato souvislost byla otestována jednoduchou lineární regresí a korelačním Pearsonovým koeficientem $R^{2}$. V tab. 7 a 8 jsou uvedeny hodnoty $R^{2}$ mezi NL a těžkými kovy a mezi NL a PAU. U těžkých kovů i PAU se hodnoty pohybují kolem 0,8, což značí silnou lineární závislost mezi koncentrací NL a PAU a mezi koncentracemi NL a testovanými těžkými kovy. Čím byla ve vzorku stanovena vyšší koncentrace NL, tím byly stanoveny i vyšší koncentrace sledovaných těžkých kovů, poprípadě PAU. Na obr. 10 je graficky znázorněn vztah mezi NL a těžkými kovy z pohledu lineární regrese. Koeficient determinace u těžkých kovů dosahuje hodnoty 0,679. Z toho vyplývá, že stanovené koncentrace kovů bylo možno lineární regresí vysvětlit z 67,9 \% pomocí naměřených koncentrací NL. U PAU (obr. 11) to Ize vysvětlit z 69,3\%.

Na základě získaných výsledků jsme ověřili, že separací NL se významně snižuje znečištění těchto vod PAU a těžkými kovy. V literatuře se však objevují i názory, že u těchto látek dochází nejen $k$ adsorpci na pevné částice, ale také k agregaci a tvorbě shluků $[6,9,10]$.

\section{ZÁVĚR}

Zvolený způsob řešení na počátku projektu vycházel z předpokladu, že významná část PAU a těžkých kovů je sorbována na pevných částicích, a odstranění NL je tak významným nástrojem k omezení vstupu PAU do vodního prostředí. Vyvinuté separační zařízení bylo odzkoušeno $v$ pilotní fázi $\vee$ modelovém měř́tku, následně byla provedena série testování prototypu v terénních podmínkách na dvou lokalitách. Lokality představovalo parkoviště a zpevněná plocha s denním využíváním vozidly silniční dopravy. Prototyp zařízení byl testován při třech zvolených průtocích $\left(0,5\left|\cdot s^{-1}, 1\right| \cdot s^{-1}\right.$ a $\left.1,5 \mid \cdot s^{-1}\right)$. Při simulaci srážkových splachů vybraných ploch bylo potvrzeno, že PAU a těžké kovy se dominantně vyskytuji ve vzorcích s NL a že nejvíce těchto látek je smyto na začátku trvání srážkové činnosti. Výsledky dosažené naším šetřením byly $\vee$ souladu s výše citovanými zahraničními studiemi. Silná lineární závislost mezi koncentrací NL a PAU a mezi koncentracemi NL a testovanými těžkými kovy byla potvrzena Pearsonovým korelačním koeficientem, jehož hodnota oscilovala kolem 0,8. Zjištěné závěry byly použity jako podklad pro následné komerční uplatnění separačního zařizení.

\section{Poděkování}

Článek vznikl rešením výzkumného projektu „Technologie separace specifických polutantů ze srážkových vod" (TH03030223). Projekt byl realizován za finanční podpory Technologické agentury České republiky. 


\section{Literatura}

11] ROMMEL, S. H., L. GELHARDT, A. WELKER a B. HELMREICH. Settling of Road-Deposited Sediment: Influence of Particle Density, Shape, Low Temperatures, and Deicing Salt. Water [on-line]. 2020, roč. 12, č. 11, s. 3126. ISSN 2073-4441. Dostupné z: doi:10.3390/w12113126

[2] DJUKIĆ, A., B. LEKIĆ, V. RAJAKOVIĆ-OGNJANOVIĆ, D. VELJOVIĆ, T. VULIĆ, M. DJOLIĆ, Z. NAUNOVIC, J. DESPOTOVIĆ a D. PRODANOVIĆ. Further insight into the mechanism of heavy metals partitioning in stormwater runoff. Journal of Environmental Management [on-line]. 2016, roč. 168, s. 104-110. ISSN 0301-4797. Dostupné z: doi: 10.1016/j.jenvman.2015.11.035

[3] LEE, J. Y. Characteristics of run-off quality and pollution loading from a highway toll-gate. Environmental Technology [on-line]. 2012, roč. 33, č. 3, s. 373-379. ISSN 0959-3330. Dostupné z: doi: 10.1080/09593330.2011.575185

[4] BLONDEEL, E., S. D. WANDEL, R. FLORIN, S. HUGELIER, M. CHYS, V. DEPUYDT, K. FOLENS, G. D. LAING, A. VERLIEFDE a S.W.H.V. HULLE. Physical-chemical treatment of rainwater runoff in recovery and recycling companies: lab-scale investigation. Environmental Technology [on-line]. 2018, roč. 39, č. 17, s. 2251-2265. ISSN 0959-3330. Dostupné z: doi: 10.1080/09593330.2017.1354074

[5] LI, Y., S.-L. LAU, M. KAYHANIAN a M. STENSTROM. Particle Size Distribution in Highway Runoff. Journal of Environmental Engineering-asce - J ENVIRON ENG-ASCE [on-line]. 2005, roč. 131. Dostupné z: doi: 10.1061/(ASCE)0733-9372(2005)131:9(1267)

[6] ČEJKOVÁ, J., A. KÓLOVÁ, J. KUČERA, M. VÁŇA, M. HOLBA a P. POLÁŠEK. Znečištění srážkových vod vybranými polutanty a jejich následné odstranění. In: Sborník prednášek a posterových sdělení 13. bienálníkonference VODA 2019. CzWA. 2019. ISBN ISSN: 2694-7013.

[7] BLONDEEL, E. M. CHYS, V. DEPUYDT, K. FOLENS, G. DU LAING A. VERLIEFDE a S. W. H. VAN HULLE. Leaching behaviour of different scrap materials at recovery and recycling companies: Full-, pilot- and lab-scale investigation. Waste Management [on-line]. 2014, roč. 34, č. 12, s. 2674-2686. ISSN 0956-053X. Dostupné z: doi: 10.1016/j.wasman.2014.08.019

[8] ČEJKOVÁ, J., A. KÓLOVÁ, J. KUČERA, M. VÁŇA, M. HOLBA a P. POLÁŠEK. Odstranění nerozpuštěných látek a vybraných polutantů ze srážkových vod. Vodní hospodárství. 2021, roč. 71, č. 1, s. str. 1-4. ISSN 1211-0760.

[9] DOUBEN, P. E. T. PAHs: An Ecotoxicological Perspective. B. m.: John Wiley \& Sons, 2003. ISBN 978-0-470-86429-6.

[10] BLONDEEL, E., V. DEPUYDT, J. CORNELIS, M. CHYS, A. VERLIEFDE a S. W. H. V. HULLE. Physical-chemical treatment of rainwater runoff in recovery and recycling companies: Pilot-scale optimization. Journal of Environmental Science and Health, Part A [on-line]. 2015, roč. 50, č. 11, s. 1083-1098. ISSN 1093-4529. Dostupné z: doi: 10.1080/10934529.2015.1047645

\section{Autoři}

Ing. Jana Čejková1

凶jana.cejkova@vuv.cz

ORCID: 0000-0001-9539-9031

\section{Ing. Anna Kólová}

凶anna.kolova@vuv.cz

ORCID: 0000-0002-8610-1501

\section{Ing. Jiří Kučera ${ }^{1}$}

凶jiri.kucera@vuv.cz

ORCID: 0000-0002-7540-4750

\section{Ing. Miroslav Váňa ${ }^{1}$}

凶miroslav.vana@vuv.cz

ORCID: 0000-0003-3367-8734

Ing. Marek Holba Ph.D. ${ }^{2}$

凶holba@asio.cz

\section{Pavel Polášek ${ }^{2}$}

凶polasek@asio.cz

'Výzkumný ústav vodohospodářský T. G. Masaryka

${ }^{2} \mathrm{ASIO}$ TECH, spol. s r. o.

Příspěvek prošel lektorským řízením

\section{TESTING OF A PROTOTYPE SEPARATION DEVICE DESIGNED FOR RAINWATER TREATMENT}

\section{CEJKOVA, J.'; KOLOVA, A.'; KUCERA, J.'; VANA, M.'; HOLBA, M. ${ }^{2}$; POLASEK, P. $^{2}$}

\section{'T. G. Masaryk Water Research Institute} ${ }^{2} \mathrm{ASIO}$ TECH, Ltd.

Keywords: rainwater treatment - stormwater run-off pollutants separation - suspended solids -

polycyclic aromatic hydrocarbons - heavy metals

The article summarizes the knowledge obtained from the project "Technology of separation of specific pollutants from stormwater" (TH03030223), addressed to the treatment of rainwater from paved areas and roads polluted by suspended solids, polycyclic aromatic hydrocarbons, and heavy metals. The aim of the project was to develop an efficient technology able to separate these pollutants from rainwater. The separation device (tested first on a model-scale and then on a pilot-scale, in a location) has proved its effectiveness in capturing suspended solids. The tests performed on the separation device confirmed the assumption stated in the literature that the removal of suspended solids significantly reduces the effluent concentration of polyaromatic hydrocarbons and heavy metals. The device based on the principle of suspended solids separation contributes to reducing a load of surface or groundwater by other pollutants, especially polycyclic aromatic hydrocarbons and heavy metals.

DOI: 10.46555/VTEI.2021.05.002 